\title{
DIFFERENTIATED INSTRUCTION IN ENGLISH LEARNING, TEACHING AND ASSESSMENT IN NON-LANGUAGE UNIVERSITIES
}

\author{
Larysa Kupchyk \\ National University of Water and Environmental Engineering, Rivne, Ukraine \\ 1.y.kupchyk@nuwm.edu.ua \\ Alona Litvinchuk \\ National University of Water and Environmental Engineering, Rivne, Ukraine \\ a.t.litvinchuk@nuwm.edu.ua
}

\begin{abstract}
This paper is aimed at resolving the problem of inadequate level of foreign language proficiency of students in non-language institutions of higher education and discussing effective approaches and methods to improve foreign language instruction at tertiary schools. An analysis of the problem by means of mixed research methods revealed the need to create positive and motivating foreign language learning environment on the basis of preliminary diagnosis through the evidence-based instructional strategies and assessment tools that make a difference in student achievements. The authors substantiate the expediency of applying differentiated instruction as a means of fostering foreign language learning by students of non-language majors, which was proved by the results of the conducted experiment. 116 Bachelor students of the National University of Water and Environmental Engineering in their first year of study took part in the experiment, which was held in academic years 2016-2017 and 2017-2018. The experiment started with the placement test, the results of which allowed grouping first-year students according to their prior knowledge of English into different groups from A1 to B2 CEFR levels. The differentiated instruction was performed in homogenous groups by means of the level-relevant content and materials, teaching methods and assessment tools. The research findings allowed the authors to contribute to improving the course design, implementing differentiated lessons, choosing appropriate teaching methods and gathering feedback. The conducted experiment also helped draw conclusions on the improvement of foreign language learning under newly created conditions, adding to high rate of productivity and flexibility of learning paths. An analysis of the experimental data showed that differentiated instruction can significantly increase students' motivation to foreign language acquisition and learning outcomes.
\end{abstract}

Keywords: experiment; differentiated instruction; method; assessment; feedback; foreign language proficiency.

\section{Introduction}

Foreign language courses supplement the curriculum of all students majoring in non-language fields of study at the universities in Ukraine. Their length and volume are different depending on the university, chosen major field of study and study programme. But in general, language training is mostly claimed to be insufficient and students often demonstrate poor foreign language skills. On the other hand, today's labour market demands specialists with a good command in foreign languages both in qualitative and quantitative aspects with special focus on English, being number one, the so called lingua franca.

This contradiction necessitates the search for new effective approaches to and methods of English as a foreign language (EFL) learning, teaching and assessment. In view of this, we consider differentiated instruction (DI) in EFL training as the one that has to be implemented in non-language higher educational establishments to promote its quality, increase students' motivation to learn and explore foreign languages throughout the learning process and throughout their whole life. Naka defines the following causes of DI implementation in EFL instruction: social and cultural background, learning ability, previous teaching, student's personality, and learning styles (Naka, 2018, p. 105).

Ukrainian researchers (Chesnokova, Sergeyeva, 2011, Grytsyk, 2016) claim that the level of foreign language proficiency of many first-year students is inadequate, especially those majoring in the fields other than Humanities. The problem is that the students often lack the required B1 level of English according to the Common European Reference for Languages (CEFR, 2018), which is determined by the Ministry of Education and Science of Ukraine as a standard of English for school leavers, and demonstrate A1 or A2 levels instead. In addition, there are students in Computer Science majors who studied at school other languages, for example, German or French, and state their willingness to start learning English as beginners. Apart from this, a few non-language first-year students hold certificates of language proficiency of B1, B2 or even C1 level (e.g. certificates of PTE, FCE or IELTS international testing centres). It results in increasingly academically diverse first-year student population. Thus, the groups formed according to the chosen major are heterogeneous, which makes the process of teaching complicated and, consequently, the learning process seems to be too difficult for many students while others may lack the challenge.

Kupchyk, L. \& Litvinchuk, A. (2020). Differentiated instruction in English learning, teaching and assessment in non-language universities. Advanced Education, 15, 89-96. DOI: 10.20535/2410-8286.168585 
One of the concepts allowing teachers to cope with the problem and respond to students' progress by observing what students already know and what they need to know as well as by giving them the opportunity to learn to their full potential is differentiation. Ukrainian and foreign researchers and practitioners in the field of education mostly use the terms differentiation or differentiated instruction (Gregory \& Chapman, 2013 Nunley, 2006, Tomlinson, 2004, Naka, 2018, etc.), ability grouping (Ireson \& Hallam, 2001), or splitlevel training (Polat, 2000). Despite a variety of terms, they all aim to create diverse language learning environments with an appropriate set of methodological, pedagogical and organisational measures to ensure students' attainments and effective advancement.

Thus, to overcome the problem of heterogeneity, contemporary methodology proposes to apply differentiation, the foundations of which were laid by the Common European Framework of Reference for Languages: Learning, Teaching, Assessment (CEFR) in 2001. It serves as a guideline to describe achievements of learners of foreign languages across Europe and beyond and it can be regarded as a means of communication and learning through differentiation, within which effective teaching cannot be done "through the same education hoops" (Gregory \& Chapman, 2013). Among a variety of definitions, we stick to the one offered by Tomlinson (2004) who defined differentiation as an instructional process of ensuring that "what a student learns, how he or she learns it, and how the student demonstrates what he or she has learned is a match for student's readiness level, interests, and preferred mode of learning" (Tomlinson, 2004, p. 188). Educators agree that teachers should investigate, find and design solutions according to the procedure from assessment of student needs to identification, analysis and hierarchy of the objectives of learning and teaching, and then to the design and implementation of differentiated lessons, evaluation and redesign depending on the student needs (Stavrou \& Koutselini, 2016). Whether teachers differentiate content, process, products, or the learning environment, the use of ongoing assessment and flexible grouping makes this a successful approach to instruction. Researchers claim that content, process and product have to be adjusted in the educational process: Anderson (2007), Nordlund (2003) classified three ways of differentiating instructions for any curricular area: modifying the content, modifying the process of learning, and modifying the product. Pham (2012) stated that "the content, process and the product should be modified" (p.12) as "the main objective of modifying the instructional process is to make every single lesson meaningful and applicable to learners in an academically enriched classroom" (p.16); Heacox (2012) supplemented the idea of modifying by "adding greater complexity, or abstractedness to the tasks by engaging students in critical and creative thinking, or by increasing the variety of ways in which you ask them to learn" (p. 11); the intended content should be challenging but controllable for all students (Bigge \& Shermis, 2004). Rock et al. (2008) developed a framework for differentiated classroom instruction that includes a comprehensive inventory and several practical strategies. Ortega et al. (2018) emphasised the advantages of DI in foreign language learning, but they claimed that DI was not "an instructional strategy but an approach for teaching and learning" (p. 1221). Theisen (2002) provided an insight into the ways of practical application of DI in the foreign language classroom, whereas Ismail and Al Allaq (2019) revealed the possibilities and advantages of DI through cooperative learning for all learners, both high and low achievers. Niculescu \& Obilisteanu (2016) and Spanou \& Zafari (2019) showed the ways of differentiation through the implementation of information and communication technologies.

Regardless of numerous studies on DI, there is no common practice for DI application through CEFR at the tertiary level of education worldwide. Little (2012) claimed that "there has been no widespread exploration by universities themselves of the potential relevance of the CEFR to third-level language curricula, teaching, learning and assessment" (p. 2). In Germany, for example, the University of Heidelberg places its students into the level-tailored course of the English language on the basis of the placement test whereas at Westsächsische Hochschule Zwickau students receive the English language instruction in heterogeneous groups.

Most universities in Ukraine teach their newcomers English for specific purposes (ESP) according to the National ESP Curriculum for Universities developed in 2005 (National ESP Curriculum, 2005). It is a usual situation when first-year students find it difficult to master field-specific vocabulary and achieve specific ESP objectives without any preliminary input from content-related courses. Another problem is the above-mentioned heterogeneity of groups. The identified problems necessitated the search for new solutions, so there was made a decision to experiment with DI within the EFL course for first-year students of Baccalaureate in the University, when grouping students and adjusting the course across the groups formed.

Thus, the objectives of this article are 1) to experimentally verify the expediency and efficiency of DI for developing English language proficiency of first-year non-language university students; 2) to demonstrate practical aspects of differentiating curricular elements within the framework of the conducted experiment. 
Comparison and analysis of previous theoretical studies, generalisation of positive experience in applying DI to EFL teaching and testing, as well as monitoring the educational process allowed the authors to formulate primary and secondary research hypotheses. It was primarily hypothesised that the use of DI can increase the level of EFL proficiency of Bachelor students in Computer Sciences at the National University of Water and Environmental Engineering (NUWEE). To further explore the primary hypothesis, the researchers assumed that the appropriate content and methods of EFL learning according to the defined CEFR levels stimulate the improvement of EFL acquisition as well as evoke and increase students' motivation to learning foreign language(s).

\section{Methods}

The research methodology of the present study was mostly based on the mixture of qualitative and quantitative methods. Qualitative research methods included reviewing literary sources and analysing the existing problem, subsequent inducing hypothesis, developing conceptual constructs, and gathering information from respondents to gain in-depth information. The quantitative research method permitted identifying the students' levels via the placement test, whereas entrance and summative assessment tests allowed measuring students' progress in the framework of the implemented DI. Processing of quantitative results was conducted by means of Bespalko's learning outcome coefficient.

Participants. 116 NUWEE Bachelor students majoring in Computer Sciences (Institute of Automatics, Cybernetics and Computer Engineering) agreed on participation in the experiment. The experimental training was conducted during academic years 2016-2017 and 2017-2018. The participants were divided into eight experimental groups according to the results of a placement test taken by them within the first week at the University. Thus, basing on the obtained results, first-year students were enrolled in the A1/A2/B1/B2-level groups with up to 15 students. The groups were formed in compliance with the aforementioned normative documents regulating the organisation of foreign language learning, teaching and assessment in NUWEE.

Apparatus and materials. The experimental teaching and educational resources consisted of 1) placement test for forming groups; 2) entrance test for assessing where students are within the level; 3 ) the methods, tasks and activities for differentiated instruction along with the formative assessment throughout the course to promote students' reading, listening, writing and speaking skills within the defined level; 4) summative assessment test at the end of the course, and; 5) consistent feedback through polls and questionnaires to respond to the student progress.

The placement test for the first-year students included 50 multiple-choice tasks from A1 to B2 CEFR levels, covering key grammar, vocabulary and functional communicative structures and was designed by the authors as an analogue to placement tests used in international practice.

Entrance and summative assessment tests (within each identified CEFR level) were performed in the form of a test which covered student's proficiency in Reading, Listening, Use of English, and Writing (Table 1).

Table 1. Structure of entrance and summative assessment tests

\begin{tabular}{|l|l|c|c|c|}
\hline \multirow{2}{*}{$\begin{array}{c}\text { Degree of } \\
\text { difficulty }\end{array}$} & \multicolumn{1}{|c|}{ Task format } & Number of & \multicolumn{2}{c|}{ Points } \\
\cline { 3 - 5 } Easy & & tasks & per task & total \\
\hline \multirow{5}{*}{ Medium } & Fill in the gap with one word only. & 24 & 0,5 & 12 \\
\cline { 2 - 5 } & Read a text. Choose the correct answer to the question. & 1 & 1 & 1 \\
\cline { 2 - 5 } & Listen to a text. Decide if each statement is true/false. & 6 & 0,5 & 3 \\
\hline & Match the words to make word collocation. & 4 & 2 & 8 \\
\cline { 2 - 5 } & Match the response with the appropriate question. & 2 & 2 & 4 \\
\cline { 2 - 5 } & Choose the correct heading to each part of the text. & 1 & 2 & 2 \\
\cline { 2 - 5 } & $\begin{array}{l}\text { Complete the gaps in the text with the appropriate } \\
\text { sentence. }\end{array}$ & 1 & 2 & 2 \\
\hline Hard & Complete the text with one word only in each place. & 1 & 8 & 8 \\
\hline \multicolumn{2}{|c|}{ Total number of points } & & $\mathbf{4 0}$ \\
\hline
\end{tabular}

To support DI, the teaching materials were tailored according to the content in which they were used. Each group was provided with a level-relevant course book and all sorts of learning resources (e.g. worksheets, charts, e-learning tools, etc.), group activity instructions, and tasks for self-dependent learning.

To elicit information on the efficiency of the applied approach and a range of other motivating forces and learning strategies, there was designed a questionnaire (Table 2), considering existing practices and our own experience. 
Table 2. Questionnaire

\begin{tabular}{|l|l|l|l|l|}
\hline No & \multicolumn{1}{|l|}{$\begin{array}{l}\text { Agree } \\
\text { agree }\end{array}$} & Disagree \\
\hline 1. & $\begin{array}{l}\text { It was important for me to find myself in the group with unanimous } \\
\text { initial level of knowledge. }\end{array}$ & & \\
\hline 2. & I was able to keep up with the other students in the group. & & & \\
\hline 3. & I found the content of the course interesting and challenging. & & & \\
\hline 4. & I could be involved in all in-class activities. & & \\
\hline 5. & I could cope with most tasks when doing them autonomously. & & & \\
\hline 6. & I felt comfortable when I saw real progress in my learning. & & & \\
\hline 7. & I found it easy to cooperate with the peers. & & \\
\hline 8. & $\begin{array}{l}\text { I found teaching methods highly adaptive and efficient not to allow } \\
\text { me to fall behind. }\end{array}$ & & & \\
\hline 9. & I feel confident and passionate about language learning. & & \\
\hline 10. & $\begin{array}{l}\text { I am ready to keep on progressing in English throughout the } \\
\text { studying process by means of compulsory courses or electives. }\end{array}$ & & & \\
\hline
\end{tabular}

The questionnaire in Table 2 offers questions of closed format where students have to choose between "agree", "partly agree" and "disagree". Google forms became a helpful tool to conduct the survey at the time and place convenient for all the students. Though it did not require much time, it provided a critical view on students' reflection on the implemented instruction.

Procedure. We set the phases of the experiment, namely: 1) hypotheses formulation, 2) teaching materials selection and design, tests development, 3) experimental groups formation, 4) experimental training, 5) research data analysis.

When assessing prior learning contributes, the participants of the experiment took the placement test used as a diagnostic tool to place students into the groups according to the results (the number of correct answers 0-15:A1; 16-29:A2; 30-39:B1; 40-50:B2).

To monitor students' progress within the defined level, students had to take the entrance test of the format stated above (Table 1). The test was assessed with 40 points.

In the course of implementing DI in the groups formed, we selected comprehensive four-level course books each covering the following topics: Personality, Employment, Holidays and Travelling, Weather, Sports and Health, Nature and Environment, Culture. The instruction demanded the choice of level-relevant methods of teaching with special attention on active methods ranging from recalling, remembering and applying at low-ability levels to analysing, making judgements and creating at high-ability levels (according to Bloom's taxonomy).

Students learning outcomes were assessed on a 100-point scale, in which 60 points were at teacher's disposal for student engagement in all in-class activities and another 40 points could be gained by first-year students taking the summative assessment test on Moodle platform at the end of the course. Tests were compiled within the aforementioned topics of the level-relevant complexity to assess reading, writing and listening skills whereas communication was practised and assessed during practical classes.

The conducted polls and questionnaires allowed getting feedback from students regarding the efficiency of teaching and their learning gains, which could help improve and refine teaching.

The levels of foreign language competence of the participants were measured by the formula $\mathrm{K}=\mathrm{A} / \mathrm{N}$ where $\mathrm{K}$ is learning outcomes coefficient, $\mathrm{A}$ is the number of points obtained for correct answers, and $\mathrm{N}$ is a maximal number of points assigned for correct answers (Bespalko, 1968). The learning outcomes coefficient of 0.7 and higher was considered to be acceptable according to Cronbach's alpha coefficient of reliability (Cronbach, 1951).

\section{Results}

Our experiment started with the placement test to identify the introductory level of EFL proficiency of the experiment participants and to place them into level-relevant groups (Fig. 1).

A2/B1-groups were considered as remedial courses as well as an opportunity for students to improve their English skills in the course of University training. The availability of A1-groups can be explained by the fact, that they were mostly filled with the students who learned at school a language other than English, but their major field of study demands knowledge of English. Among the students participating in the experiment, the number of students of B2-groups amounted to only $26.3 \%$ in the academic year 2016-2017 and $25.4 \%$ in the academic year 2017-2018. 


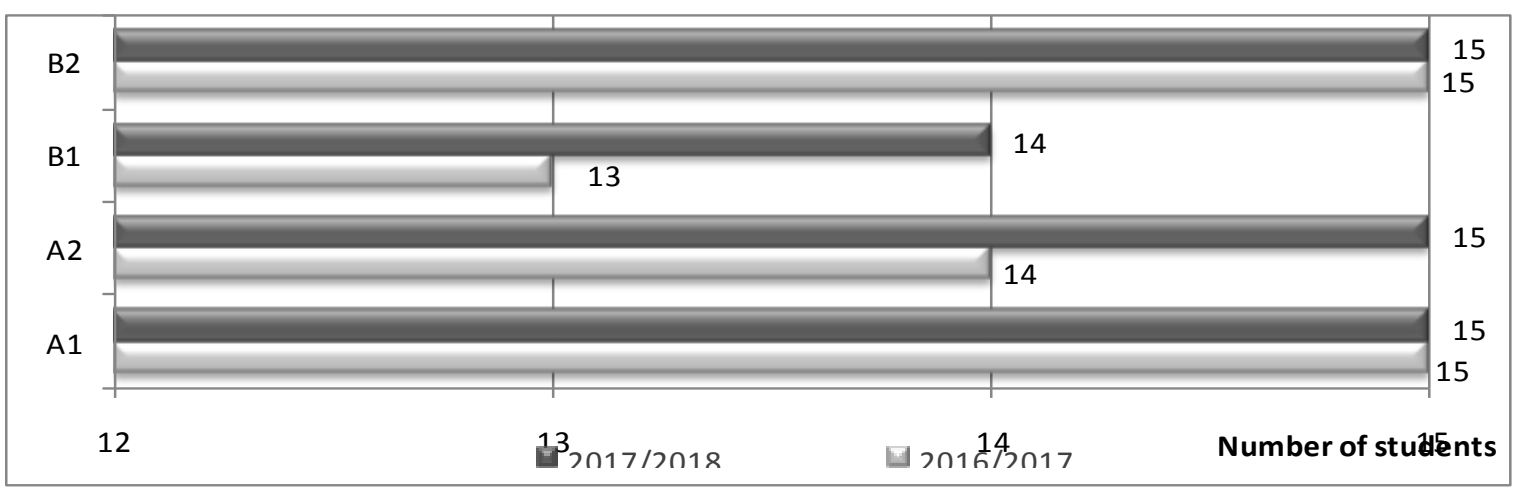

Fig. 1. English Placement Test Results

To identify the EFL proficiency within the level, students were offered to take the entrance test, the results of which were computed on the basis of the evaluation criterion "correct answer to test question" (points were awarded for choosing correct options) and are presented in Table 3.

Table 3. Results of entrance test under the condition of CEFR level application

\begin{tabular}{|c|c|c|c|c|}
\hline Experimental groups & CEFR Level & Number of students & $\begin{array}{c}\text { Coefficient of entrance } \\
\text { test results }\end{array}$ & $\begin{array}{l}\text { Mean } \\
\text { value }\end{array}$ \\
\hline \multicolumn{5}{|c|}{ Academic year 2016-2017 } \\
\hline Experimental group 1 & A1 & 15 & 0.2 & \multirow{4}{*}{0,51} \\
\hline Experimental group 2 & $\mathrm{~A} 2$ & 14 & 0.55 & \\
\hline Experimental group 3 & B1 & 13 & 0.61 & \\
\hline Experimental group 4 & $\mathrm{~B} 2$ & 15 & 0.68 & \\
\hline \multicolumn{5}{|c|}{ Academic year 2017-2018 } \\
\hline Experimental group 5 & A1 & 15 & 0.25 & \multirow{4}{*}{0,505} \\
\hline Experimental group 6 & $\mathrm{~A} 2$ & 15 & 0.54 & \\
\hline Experimental group 7 & $\mathrm{~B} 1$ & 14 & 0.6 & \\
\hline Experimental group 8 & $\mathrm{~B} 2$ & 15 & 0.63 & \\
\hline
\end{tabular}

At the end of the course, students had to take a summative assessment test, the results of which showed the progress in mastering the English language (Table 4). These results were computed according to the same evaluation criterion as the entrance test.

Table 4. Results of summative assessment test under the condition of CEFR level application

\begin{tabular}{|c|c|c|c|c|}
\hline Experimental groups & CEFR Level & Number of students & $\begin{array}{c}\text { Coefficient of } \\
\text { summative assessment } \\
\text { test }\end{array}$ & $\begin{array}{l}\text { Mean } \\
\text { value }\end{array}$ \\
\hline \multicolumn{5}{|c|}{ Academic year 2016-2017 } \\
\hline Experimental group 1 & A1 & 15 & 0.72 & \multirow{4}{*}{0,81} \\
\hline Experimental group 2 & A2 & 14 & 0.79 & \\
\hline Experimental group 3 & $\mathrm{~B} 1$ & 13 & 0.84 & \\
\hline Experimental group 4 & B2 & 15 & 0.9 & \\
\hline \multicolumn{5}{|c|}{ Academic year 2017-2018 } \\
\hline Experimental group 5 & A1 & 15 & 0.74 & \multirow{4}{*}{0,82} \\
\hline Experimental group 6 & $\mathrm{~A} 2$ & 15 & 0.8 & \\
\hline Experimental group 7 & B1 & 14 & 0.82 & \\
\hline Experimental group 8 & B2 & 15 & 0.91 & \\
\hline
\end{tabular}

Consequently, the average coefficient of summative assessment results for experimental groups 1 and 5 was 0.73 , for groups 2 and 6 it reached 0.795 , for groups 3 and $7-0,83$, and for groups 4 and 8 it amounted to 0,915 . Alpha values for the total sample ranged from 0.7 to 0.91 and therefore, indicated that the scale provided internal consistency. 
Table 5. Comparative analyses of tests results obtained

\begin{tabular}{|l|c|c|}
\hline Experimental groups & $\begin{array}{c}\text { Coefficient of entrance test } \\
\text { results }\end{array}$ & $\begin{array}{c}\text { Coefficient of summative } \\
\text { assessment test results }\end{array}$ \\
\hline \multicolumn{3}{|c|}{ Academic year 2016-2017 } \\
\hline Experimental group 1 & 0.2 & 0.72 \\
\hline Experimental group 2 & 0.55 & 0.79 \\
\hline Experimental group 3 & 0.61 & 0.84 \\
\hline Experimental group 4 & 0.68 & 0.9 \\
\hline \multicolumn{3}{|c|}{ Academic year 2017-2018 } \\
\hline Experimental group 5 & 0.25 & 0.74 \\
\hline Experimental group 6 & 0.54 & 0.8 \\
\hline Experimental group 7 & 0.6 & 0.82 \\
\hline Experimental group 8 & 0.63 & 0.91 \\
\hline
\end{tabular}

According to Table 5, all experimental groups managed to achieve positive results. The results of experimental groups 1 and 5 showed the best dynamics, i.e. the results of experimental group 1 increased by 3.6, and learning outcomes of experimental group 5 have nearly tripled. The results of Table 5 also reveal that the higher the language level of the group is, the higher the results are.

To provide a comprehensive picture of the strengths and weaknesses of the performed experiment and encourage students to reflect on their learning practices, there was created a survey using Google Forms Questionnaire. There were approximately 116 students eligible to answer a set of questions.

Table 6. Questionnaire results

\begin{tabular}{|c|c|c|c|c|c|c|c|}
\hline $\begin{array}{c}\text { Question } \\
\text { number }\end{array}$ & Agree, \% & $\begin{array}{c}\text { Partly } \\
\text { agree, \% }\end{array}$ & $\begin{array}{c}\text { Disagree, } \\
\mathbf{\%}\end{array}$ & $\begin{array}{c}\text { Question } \\
\text { number }\end{array}$ & Agree, \% & $\begin{array}{c}\text { Partly } \\
\text { agree, \% }\end{array}$ & $\begin{array}{c}\text { Disagree, } \\
\text { \% }\end{array}$ \\
\hline Q 1 & 80 & 13 & 7 & Q 6 & 94 & 6 & 0 \\
\hline Q 2 & 92 & 8 & 0 & Q 7 & 73 & 19 & 8 \\
\hline Q 3 & 89 & 7 & 4 & Q 8 & 89 & 10 & 1 \\
\hline Q 4 & 67 & 21 & 12 & Q 9 & 84 & 13 & 3 \\
\hline Q 5 & 65 & 26 & 9 & Q 10 & 71 & 19 & 10 \\
\hline
\end{tabular}

Analysis of 104 completed questionnaires (89.7\%) distributed among the students-participants of the experiment revealed that DI might be characterised by considerable potential benefits. When analysing questionnaire results shown in Table 6, we were able to conclude that the majority found themselves in positive learning environments and advantaged of continual working at an appropriate level. Most respondents admitted that DI allowed them to develop a deep understanding of what they were learning; they did not suffer from lagging behind their peers and found it easy to cooperate with them.

\section{Discussion}

In the course of the conducted experiment, the following problems arose:

1. How does the teacher determine where students are in relation to the learning goal?

2. How does the teacher adjust instruction to address students' needs?

3. How does the teacher approach assessment and student feedback?

It can be argued that the University entrants have to be equipped with the knowledge of English at B1level at school that contradicts the existing practices and thus becomes an obstacle to achieving the required learning outcomes. The process under study enabled providing equal opportunities for the students with different level of EFL proficiency in the environment that enhances their self-assuredness and selfconfidence through forming groups according to their abilities on the basis of the placement test results. Students were certain to prefer the learning environment specifically designed to meet their needs and opportunities that can only be achieved by adapting the strategies and teaching practices according to their level of knowledge. They were positive about collaborating at all levels, having hardly any reasons for declining to participate in and showing little fear to different kinds of activities. The teachers, in their turn, found it easy to determine the factors inhibiting learning efficiency and those promoting students' interest and motivation to EFL learning. Moreover, DI made it possible to design and deliver instruction, starting from where the students were and moving them forward on a learning continuum.

The formation of experimental groups was followed by providing each group with a particular syllabus and teaching resources, viewing the relevant content, structure and assessment. We designed learning 
modules according to the CEFR proficiency levels that specify: 1) the minimum proficiency in listening, reading and spoken interaction, spoken production and writing that students need to obtain within the module; 2) the learning outcomes in terms of CEFR activities and levels. The core content was mainly explored in tutorials; and within their self-dependent work, students could focus on the linguistic challenges posed by the source materials and the productive tasks (e.g. essays, PowerPoint presentations, projects) in written and oral forms. Besides, the teachers were able to distinguish lesson pacing from slow for low-ability groups to fast for high ones. Low-ability students were provided with needed repetition, reinforcement and teacher's direction (e.g. through mind-maps associations, Cinquain-writing, etc.), while high-ability students were offered more challenging material, stimulating student involvement in investigating, synthesis, problem solving and creating (e.g. argumentation maps, jigsaw, debates, etc.). Among other active methods which proved efficient were flipped classroom, think - pair - share, project activities, jigsaw, learning by teaching (peer instruction), one-minute paper / muddiest point paper, etc.; they were aimed at making students collaborate in and outside the classroom.

To assess student progress within each CEFR level during practical classes, we tried to establish clear, valid and reliable standards of achievement for each learning outcome according to the following assessment criteria: quality, accuracy, fluency and coherence of language proficiency, student active participation.

While taking summative assessment test, most students saw real progress in their learning and performed well on both production and comprehension in English. An analysis of the results also helped decide on making strategic decisions on instructional improvements.

Continuous evaluation and adjustment of the modes of delivery and pedagogical methods were done when gathering feedback from students based on either paper or online anonymous polls or surveys completed at the end of each class. Regular online polling, e.g. on Telegram, was aimed at highlighting the breadth and depth of students' participation in and reflection on in-class activities. The results of the polls also became a decisive factor for the teachers to adjust current teaching tactics. Anonymity gave students the courage to speak out; and student feedback became a useful tool in the process of students' self-assessment. Based on the analysis of students' answers in the post-experiment questionnaire, we found that students managed to compensate for insufficient language skills, overcome the language barrier, and acquire autonomy and the ability to manage the learning process without the help of a teacher.

Being a developmental process, language learning must be provided with successive stages each of which represents growth and expansion of the students' ability to learn, know, use and critically think in a new language. For this reason, the obligatory course of a foreign language, which is usually insufficient, is complemented with a wide range of electives, which can permit increased flexibility for students across programme pathways (Hedges, Pacheco, Webber, 2013, p. 4). The range of elective courses has been specifically designed to provide the continuous process in foreign language education, encompassing both successions in mastering the levels of foreign language competence (according to the CEFR) and those devoted to acquiring practical skills in particular aspects, such as grammar (at different levels), vocabulary, writing or speaking, as well as foreign language courses for specific purposes.

\section{Limitations}

Despite the positive dynamics of DI, the study was limited only to 116 students of the Institute of Automatics, Cybernetics and Computer Engineering of NUWEE (Rivne, Ukraine). The research would provide more accurate results than it did if it covered all NUWEE first-year students.

\section{Conclusions}

The priority of DI that enables educators to plan strategically in order to meet the needs of diverse learners necessitates reviewing the existing system of EFL acquisition in non-language higher education. The results of DI implementation have revealed new possibilities for students to improve their command of English. The conducted experiment exemplified the rationale of the newly created conditions of teaching in groups with homogenous initial level of EFL proficiency. Its implementation was achieved through the relevant form- and content-relevant and effective methods of delivery, which were highly adapted to the appropriate level. The efficiency of the used teaching practices was justified by the results of the conducted experiment reinforced by anonymous polls at the end of each class providing high rate of feedback and reflection from students. The questionnaire at the end of the year proved students' satisfaction with the provided opportunities of equality, supportive learning environment, which added to their self-confidence and increased motivation to continue their language learning.

The given research may be of particular interest for practitioners, especially foreign language teachers at non-language universities, who are in constant search for the most effective ways introducing the greatest 
exposure to students. Major merits and contributions of the conducted experiment to the methodology of foreign language teaching are presented by a series of adaptive decisions on learning pathways characterised by high rate of homogeneity and progressing opportunities for all students disregarding their initial level of foreign language command. Consequently, by creating highly motivating learning environment and using level-relevant learning methods, providing constant feedback and reflection, students are likely to become more enthusiastic about formation of foreign language competence.

Perspectives for further research will include more detailed consideration of the mechanism of implementing DI and elucidation of ways to improve teaching and learning activities, content, communication strategies, and assessment tasks aligning with the course-intended learning outcomes.

\section{References:}

Anderson, K. M. (2007). Tips for teaching: Differentiating instruction to include all students. Preventing School Failure, 51(3), 4954. https://doi.org/10.3200/psfl.51.3.49-54

Bespalko, V. P. (1968). Opyt razrabotki i ispol'zovanija kriteriev kachestva usvoenija znanij [Experience in developing and applying evaluation criteria for knowledge acquisition]. Sovetskaja pedagogika, 4, 52-59.

Bigge, M. \& Shermis, S. (2004). Learning theories for teachers. 6th ed. Boston, MA: Pearson.

Chesnokova, H. V. \& Sergeyeva, M. V. (2011). Bilingvalna sytuatsija v Ukraini, abo Chomu ukrajintsi ne rozmovliajut' anglijskoju [Bilingual situation in Ukraine, or Why Ukrainians do not speak English]. Humanitarna osvita u vyshchykn technichnykh navchalnykh zakladakh, 23, 82-96. Retrieved 15 Feb. 2019, from http://nbuv.gov.ua/UJRN/gotvnz_2011_23_12

Council of Europe (2001). Common European Framework of Reference for Languages: Learning, teaching, assessment. Cambridge: Cambridge University Press. Available at www.coe.int/lang

Council of Europe (2018). Common European Framework of Reference for Languages: Learning, teaching, assessment. Companion volume with new descriptions. Strasbourg Cedex. Retrieved 15 Feb. 2019 from https://rm.coe.int/cefr-companion-volumewith-new-descriptors-2018/1680787989

Cronbach, L. J. (1951). Coefficient alpha and the internal structure of tests. Psychometrika, 16 (3), $297-334$. https://doi.org/10.1007/bf02310555.

Gregory, G.H \& Chapman, C. (2013). Differentiated instructional strategies: One size does not fit all. Sage publications.

English for Specific Purposes (ESP) National Curriculum for Universities (2005). Ministry of Education and Science of Ukraine. British Council Ukraine. Kyiv, Ukraine: Lenvit.

Grytsyk, N. (2016), Implementing European Standards in the ESP Curriculum for Students of Non-Linguistic Specialities in Ukrainian Universities. Advanced Education, 5, 4-8. https://doi.org/10.20535/2410-8286.60757

Heacox, D. (2012). Differentiating instruction in the regular classroom. Minneapolis: Free Spirit Publishing Inc.

Hedges, M. R, Pacheco, G. A, \& Webber, D. J. (2013). What determines students' choices of elective modules. Economics Working Paper Series, University of the West of England, Bristol, UK. Available at https://www2.uwe.ac.uk/faculties/BBS/BUS/ Research/Economics13/1307.pdf

Ireson, J. \& Hallam, S. (2001). Ability grouping in Education. London, Great Britain: Paul Chapman Publishing.

Ismail, S. A.A. \& Al Allaq, Kh. (2019). The Nature of Cooperative Learning and Differentiated Instruction Practices in English Classes. SAGE Open, 9(2). https://doi.org/10.1177/2158244019856450

Little, D. (2012). The Common European Framework of Reference for Languages, the European Language Portfolio, and language learning in higher education. Language Learning in Higher Education. Journal of the European Confederation of language Centres in Higher Education 1(1), 1-21. https://doi.org/10.1515/cercles-2011-0001

Naka, L. (2018). Differentiated Instruction in Foreign Language Learning in Undergraduate Studies. Journal of Literature, Languages and Linguistics, 42, 101-112. Retrieved on 18.06.2020 from https://iiste.org/Journals/index.php/JLLL/article/view/41772/0

Niculescu, B.-O. \& Obilișteanu, G. (2016). Related Aspects between ICT and the Modernization of Differentiared Individualized Teaching of Foreign Languages in Higher Education. Scientific Bulletin, 21(1), 28-35. https://doi.org/10.1515/bsaft-2016-0033

Nordlund, M. (2003). Differentiated instruction: Meeting the educational needs of all students in your classroom. Maryland, Scarecrow Press.

Nunley, K. (2006). Differentiating the high school classroom: Solution strategies for 18 common obstacles. Thousand Oaks, CA: Corbin.

Ortega, D.P., Cabrera, J.M., Banalcásar, J.V. (2018) Differentiated Instruction in the Language Learning Classroom: Theoretical Considartions and Practical Applications. Journal of Language Teaching and Research, 9(6), 1220-1228. http://dx.doi.org/10.17507/jltr.0906.11

Polat, Y.S. (2000). Raznourovnievoye obucheniye [Split-level training]. Inostrannyye yazyki v shkole, 6, 6-11.

Pham, H. L. (2012). Differentiated instruction and the need to integrate teaching and practice. Journal of College Teaching \& Learning, 9(1), 13-20. https://doi.org/10.19030/tlc.v9i1.6710

Rock M. L., Gregg M., Ellis E., Gable R.A. (2008). REACH: A Framework for Differentiating Classroom Instruction. Preventing School Failure: Alternative Education for Children and Youth, 52(2), 31-47. https://doi.org/10.3200/PSFL.52.2.31-47

Spanou, S., Zafiri, M.-N. (2019). Teaching Reading and Writing Skills to Young Learners in English as a Foreign Language Using Blogs: A Case Study. Journal of Language and Cultural EducatHerion, 7(2), 1-20. https://doi.org/10.2478/jolace-2019-0009

Stavrou, T. \& Koutselini, M. (2016). Differentiation of Teaching and Learning: The Teachers' Perspective. Universal Journal of Educational Research, 4(11), 2581-2588. https://doi.org/10.13189/ujer.2016.041111

Theisen, T. (2002). Differentiated instruction in the foreign language classroom: Meeting the diverse needs of all learners. The Communiqué, 6, 1-8. Retrieved 15 Nov. 2019 from https://www.sedl.org/loteced/communique/n06.pdf.

Tomlinson, C. A. (2004). Sharing responsibility for differentiating instruction. Roeper Review, 26 (4), 188-200. https://doi.org/10.1080/02783190409554268 